\title{
The Implementation of Multisensory Technique for Children with Dyslexia
}

\author{
Agus Supriatna $^{1 \star}$, Ediyanto $^{2}$ \\ ${ }^{1}$ Pusat Pengembangan dan Pemberdayaan Pendidik dan Tenaga Kependidikan Taman \\ Kanak-kanak dan Pendidikan Luar Biasa \\ ${ }^{2}$ Pendidikan Luar Biasa, Fakultas Ilmu Pendidikan, Universitas Negeri Malang
}

\begin{abstract}
Children with learning disabilities are a children's physiological or biological condition in which the competence or achievement is not according to predetermined standard criteria-learning disabilities in the form of errors in reading called dyslexia. Children with specific learning difficulties dyslexia experience difficulties in academic aspects; therefore, it is necessary to carry out an academic assessment and material for tutors to improve dyslexia reading skills. The multisensory technique is alternatives that used as reference material for tutors to improve dyslexia reading skills. Multisensory Techniques that can be used include 1) Reading and Spelling Training; 2) Visual Technique; 3) Auditory Technique, and 4) Tactile Technique. The reading and spelling focus on maintaining relationships between sounds and symbols starts with a single letter and continues with consonant combinations, vowel continuation, and complex letter groupings. The Visual Technique can start by using a picture card with the word written on the bottom (flashcard). Auditory technique for children who have difficulty with sound problems, teach a pair of short words and ask the child to say which word is correct. In addition, children with dyslexia will have the best learning by touch, so it is essential to incorporate this learning style into the instruction as a tactile technique.
\end{abstract}

Keywords: Multisensory Technique, Dyslexia, Children with Dyslexia

\section{Research Background}

Children who have learning difficulties, often referred to as learning problems or learning difficulties, are group learning disabilities (LD) or Specific Learning Difficulties (SLD) (Ummah, 2018; Amelia, 2016). The problem of learning difficulties in children who have special needs, both temporary and permanent, will directly impact the learning process in the form of barriers to learning and development (Kiswantoro, Lestari, \& Zamroni, 2017). For example, learning difficulties in children that is caused by visual impairment (blind), hearing and speech disorders (deaf/speech), intelligence disorders (gifted and genius mental retardation), limb disorders (disabled), behavioral and emotional disorders (hearing impairment), slow learners (slow learner), autism, or ADHD will have an impact on the learning process according to the level of difficulty. This training focused on discussing learning difficulties for children with special needs in 
inclusive elementary schools who experience specific learning disorders, namely dyslexia.

Children with learning disabilities (LD) or Specific Learning Disabilities (SLD) in general can be defined as a learning difficulty in children characterized by the inability to follow lessons properly and impact their academic results. This view is in line with the case of Anna Surti Ariani, Psi, and LD in http://www2.kompas.com/ Friday, June 22, 2007, which defines learning difficulties as barriers or learning disorders children or adolescents which are marked by a significant gap between intelligence levels. Moreover, academic abilities should be achieved by children his age.

Children with LD or SLD are primary learning problems caused by a deficit or lack of function in one or more areas of intelligence. The cause is neurological and genetic disorders. The term LD or SLD is only applied to children who have normal to high intelligence. This disorder is visible in the form of errors in reading (dyslexia), writing (dysgraphia), and arithmetic (dyscalculia). The mistakes that occur will always be the same continuously and carried on for life (long live disabilities) (Widyorini and Van Tiel, 2017).

The presence of certain accompanying disorders characterizes the LD group of children. According to Cruickshank (1980), these disorders are background-figure, visualmotor, visual-perceptual, auditory, intersensory, conceptual and abstract thinking, language, socio-emotional, body image, and self-concept disorders. Hammil and Myers (1975) view include disturbances in motor activity, perception, attention, emotionality, symbolization, and memory. From an academic perspective, most LD children also experience significant failures in mastering basic learning skills, such as reading, writing, and/or arithmetic.

\section{Research Theory}

\subsection{The Definition of Specific Learning Difficulties.}

Learning difficulty is a condition in which competence or achievement is not in accordance with predetermined standard criteria (Haryatni, 2014; Suryani, 2010; Ghufron, 2015). Biological or physiological factors generally cause such conditions, especially concerning abnormalities in brain function, which are commonly referred to as specific learning difficulties, as well as psychological factors, namely learning difficulties related to low motivation and interest in learning (Sudarsana and Suarni, 2020; Silalahi, 2020; Lorenza 2019; Damanik, 2017).

In general, learning barriers/disorders in children and adolescents are marked by a significant gap between the level of intelligence and academic ability that should be achieved (Syaifudin and Wijaya, 2016; Sadieda and Cahyani, 2017). This gap is caused by disturbances in the brain's central nervous system (neurobiological disorders), which can cause developmental disorders such as developmental disorders of speech, reading, 
writing, understanding, and counting (Sudarsana and Suarni, 2020). Children in school generally have different individual characteristics, either physically, mentally, intellectually, or socio-emotional.

Starting from the explanation above, the children will experience various learning problems according to their characteristics and potentials. The term "specific learning difficulties" describes all children who have a disturbance in one or more basic psychological processes involving the understanding or use of language, spoken or written, where the disorder can manifest itself as an imperfect ability to hear, think, speak, read, write, spelling, or doing math calculations (Trijayanti, 2019 and Pujianingsih, 2011).

In that term, conditions include perceptual disorders, brain injury, minimal brain dysfunction, dyslexia, and developmental aphasia. This term does not include learning problems whose leading cause is visual, hearing, or motor impairment, mental retardation, emotional distress, or environmental, cultural, or economic disadvantage. The definition above contains several main concepts as follows (Pujianingsih, 2011):

1. A person who has a disorder in one or more of the basic psychological processes includes mental abilities such as memory, auditory perception, visual perception, spoken language, and thought processes.

2. Learning difficulties can appear as difficulties in speaking, listening, writing, reading (recognizing words and understanding), and mathematics (calculation and reasoning).

3. Problems that are not directly caused by sensory disorders (vision, hearing), intellectual disabilities, environmental disadvantages.

4. The a significant gap between the learning potential that is owned and the low level of learning achievement.

Based on the National Joint Committee for Learning Disabilities (NJCLD), learning difficulties refer to a group of difficulties that manifested in difficulties in proficiency and use of listening, conversing, reading, writing, reasoning, or mathematics abilities. The disorder is intrinsic and thought in nature to be caused by a central nervous system dysfunction. Although a learning difficulty may coexist with the presence of other conditions (for example, sensory impairment, intellectual disability, social and emotional disturbance) or environmental influences (cultural differences, inappropriate learning process, psychogenic factors), these obstacles are not the cause. or direct influencer (Martins, Amato, Tomczyk, Oyelere, Eliseo, \& Silveira, 2020; Leko, Brownell, \& Lauterbach, 2010)

\subsection{Specific Learning Difficulties in Reading (Dyslexia)}


Specific learning difficulties are known as /dyslexia/ which comes from Greek, namely /dys/ means difficulty, and /lexis/, which means language, so dyslexia means specific learning difficulties in the form of reading, spelling, and writing difficulties, which are not comparable to their level of intelligence.

Peer (2002: 45) defines that student who have difficulty learning dyslexia are the difficulties associated with written words or symbols. This disorder is caused by the inability to connect between spoken and written words or difficulty recognizing the relationship between sound and written words. Furthermore, Paat (2006) explained that children with learning disorders dyslexia have problems with meta-cognition abilities. In other words, the child has difficulty managing understanding when receiving information or giving incorrect responses.

When comparing dyslexic children with general children in developing reading skills, general children's reading abilities have appeared since the age of six or seven. Unlike children with dyslexia, until the age of twelve, sometimes they are still not fluent in reading. Thus, dyslexia is a disorder of children's reading ability that is below their supposed ability. This disorder is not a form of physical disability, such as a vision problem, but refers to how the brain processes and processes the information the child is reading. This difficulty is usually detected only after the child has entered the school world for some time.

A. The Symptoms of Dyslexia

There are several characteristics of dyslexia, including:

1. this disorder can be seen from the elementary school age;

2. will have trouble reading who is slow and has poor writing;

3. likes to reduce or add words while reading;

4. Experiencing errors when reading such as the letter "p" is considered "q" and the letter "b" is considered "d";

5. often reverse the words; for example, the book reads "duku," smells with "fruit," is blind with "stones," etc.;

6. For example, I like to exchange conceptual understanding, confused about understanding the top with bottom, front with back, and so on. Sometimes accompanied by the articulation of a stuttering voice and

7. often accompanied by misspellings and typos. For example, if the word hashtag was dictated, it might be written as "exposed." These typographical errors also include the inability to create beautiful, often illegible writing.

Moreover, according to the PLB Directorate (2000), the characteristics of students who experience dyslexia can be seen from the following: 
1. Children who have difficulty reading (dyslexia).

2. Development of late reading skills.

3. The ability to understand the content of the reading is low.

4. If you read, there are often many mistakes.

Paat (2006) strengthened the opinion above, who explains that identifying dyslexic children can be seen from the following activities.

1. Difficult to spell correctly. One word can be pronounced many times with various words.

2. It is not easy to spell words or syllables with similar shapes, for example, b-d, u-n, or m-n.

3. When reading, children often go wrong to the next paragraph or not in order.

4. Difficulty sorting letters in words.

5. Spelling mistakes that are done continuously. For example, the word "lesson" is pronounced "sollen."

More completely, as Davis (2005) stated in identifying and the characteristics of students who have specific learning difficulties like dyslexia can be seen from the indicators below.

1. Slow to speak when compared to most children his age and unable to pronounce words correctly.

2. Slowly recognize the alphabet, numbers, days, weeks, months, colors, shapes, and other essential information. Furthermore, it is not easy to sort the letters in words.

3. Difficult to voice phonemes (sound units) and combine them into a word.

4. Difficult to spell correctly. Maybe the child will even spell a word with different words.

5. Difficulty spelling words or syllables correctly. Children are confused about letters with similar forms such as b - $d, u-n, m-n$.

6. Read one word correctly on one page but wrong on another.

7. Difficulty understanding what is being read.

8. Often reversed in writing or saying words. For example, the word "elephant" is pronounced "dashing," "lesson" is read as "journey."

9. Have a habit of reading too fast to mispronounce words or even too slow and intermittent.

10. Confusion in understanding the concept of left-right, up-down, northsouth, east-west.

11. Difficulty following more than one instruction at the same time.

B. Factors causing Dyslexia 
The reasons for students experiencing dyslexia, according to Davis (1997), are broadly based on three factors, namely as follows.

1. Genetic/hereditary. Dyslexia tends to run in families that have lefthanded members. However, parents who have dyslexia do not automatically pass the disorder on to their children, or left-handed children have dyslexia.

2. They are having hearing problems from an early age. If difficulties are not detected early, the developing brain will find it challenging to connect the sounds or sounds they hear with the letters or words they see. This challenge is evident from international research (Peer, 2002). With a sample of 1000 young people with dyshowsshowig, the number of people with a history of ear infections, especially glue ear, is 703. This research indicates a sub-group of students with dyslexia who have an early history like this. This study's key findings suggest that the glue ear subgroup was more likely to have more severe dyslexia than those in the dyslexic group but did not have glue ears. It should also be noted that, while the majority of children around the world experience glue ear in their early years (Daly, 1997), only a tiny proportion of the disease gets worse and continues to suffer from this disease.

Sound wave produce vibration. Hearing will be clear if nothing gets in the way

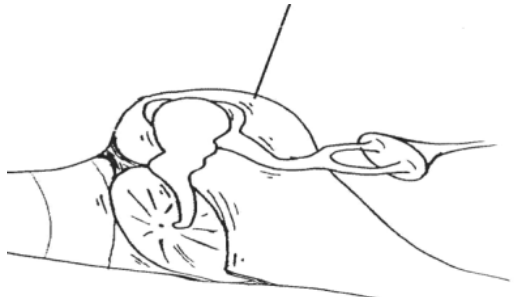

Image 1a. Healthy Ear
The liquid gets in the way so the sound is very limited

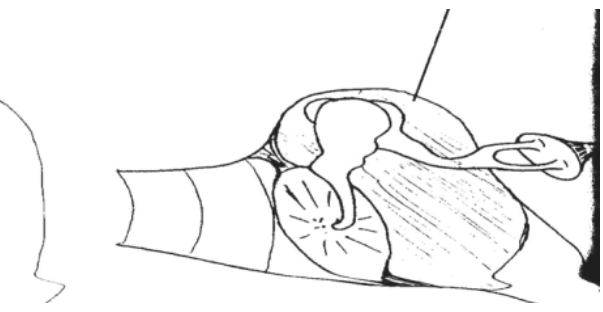

Image 1b. Unhealthy Ear

Picture 1. How is Glue Ear affecting the hearing?

1. Combination factors. It is a combination of the two things. This combination factor causes dyslexic children to become more severe or severe, requiring thorough and continuous treatment.

There are several differences between the brain of dyslexic children and general children. The first difference is that the dyslexic children's brains show no asymmetry at the brain's language centers in the temporal region. In ordinary children, the left 
hemisphere's temporal area is more significant than that of the right. In dyslexic children, left and right are the same. The second difference is that in dyslexic children, there are nerve cell disorders in several brain areas related to reading ability, for example, in the parietal and temporal areas. This nerve cell disorder has occurred since the child was still in the womb.

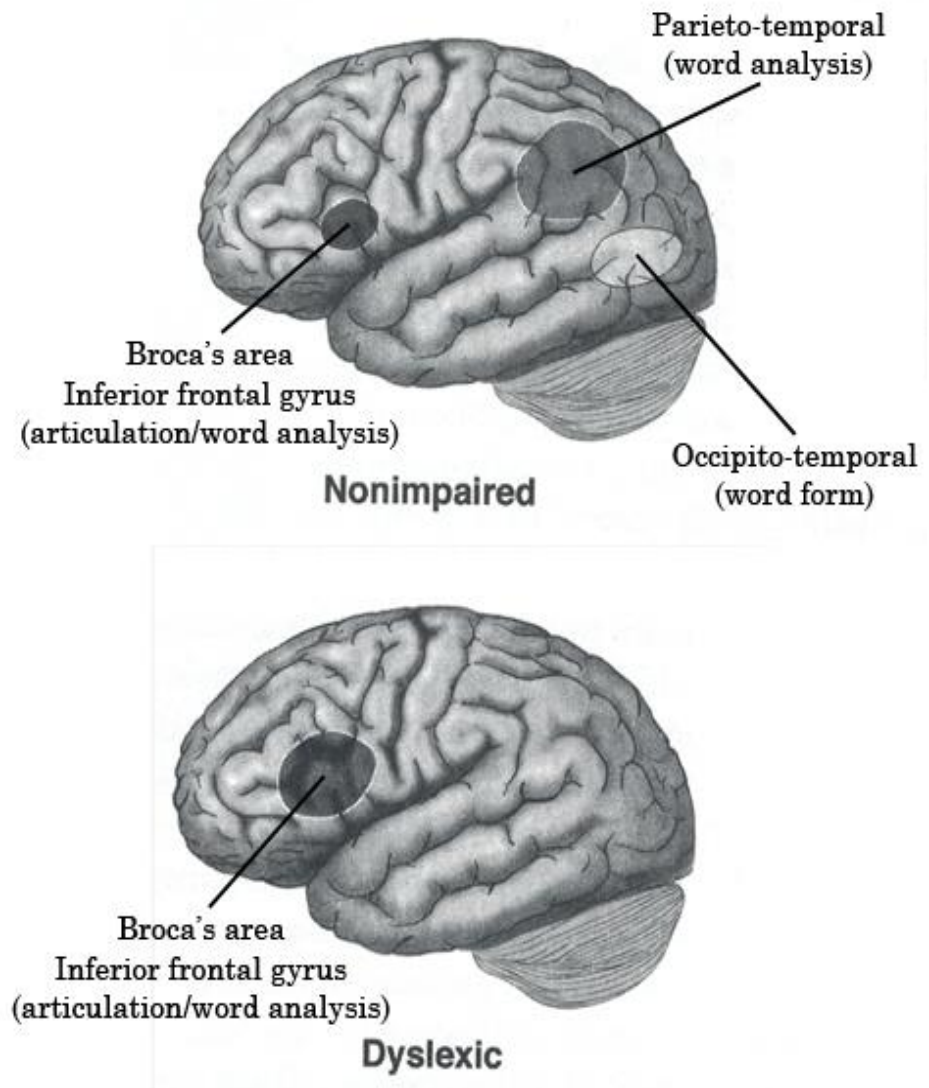

Picture 2. The brain of the dyslexic child

Based on the views above, there are several facts found by Peer (2002) that;

1. Dyslexia always affects the writing process, especially spelling.

2. In most cases, it is hereditary, but sometimes not hereditary.

3. People from all language communities can develop dyslexia. Becoming a multilingual person can make matters worse, but this is not the cause.

4. You may have low memory and are both intelligent and dyslexic!

5. Sometimes dyslexia affects reading and/or learning mathematics and/or music notation.

6. People with dyslexia usually feel that they know more in their head than what they can write on paper, which can be very frustrating.

7. People with dyslexia often find that the speed of speaking of others is too high.

8. Sometimes people with dyslexia feel that the pages they are reading move that make reading difficult for them.

9. You cannot become dyslexic through bad teaching. 
10. Incurable! This is not a disease!

\section{Method}

The current study used a literature review method with the objectives to describe the implementation of a multisensory technique for children with Dyslexia. The steps used in this study are selecting keywords according to the study objectives. There are three-step: a). articles selection, b). analysis of the study, and c) article categorization. The researcher used the article selection to find each of the topics discussed in this study. The first problem is the definition of Dyslexia and then "implementation of a multisensory technique for children with Dyslexia."

\section{Results}

\subsection{Identification and Assessment of Student with Dyslexia}

Children with learning difficulties, specifically dyslexia, show abnormalities in one or more of the basic psychological processes involved in understanding or using spoken or written language that can be manifested in impaired listening, thinking, reading, and spelling (Fatoni, \& Ainin, 2019). They include conditions referred to as perceptual disorders, brain injuries, minimal brain dysfunction, dyslexia, development of aphasia, etc. Children with learning difficulties do not include learning problems mainly due to visual, hearing, or motor disabilities, intellectual disability, emotional disturbances, or adverse environmental conditions. Dyslexic children can be identified by the existence of a significant difference between what they are able to do and what they achieve, namely, a marked low achievement in related school activities or language (Widyorini and Van Tiel, 2017).

Based on the above understanding, children with specific learning difficulties dyslexia experience difficulties in academic aspects. Therefore it is necessary to carry out an academic assessment. The following will discuss the scope that must be assessed in the academic area. Reading is decoding or converting written symbols in the form of letters or words into sound systems or the like. This decoding process, of course, involves sensing and visual perception. Visual perception is highly dependent on sensations in the body and gravity. If these sensor systems do not work correctly, visual processing will be disturbed, including reading ability (Ayres, 1979). For this reason, reading assessments need to be carried out on children who are thought to have specific learning difficulties.

Usually, children with specific learning difficulties experience reading problems, which are indicated by errors in pronunciation, missed words or sentences, or not understanding the meaning of the sentence being read. There are even children who have difficulty reading unfamiliar words. These difficulties can have a further impact on academic achievement. The reading skills assessment includes pre-reading and reading skills. Pre-reading skills include observing the following: 
1. Associate sounds with letters and recognize the start and end sounds of words.

2. Can participate in activities related to rhythmic sounds.

3. Use understanding of the sound of letters in reading and writing simple words.

4. Have an interest in books.

5. Understand that every article contains a message.

6. Shows an understanding of the story's elements such as the main character, the sequence of events, the beginning and end of the story.

7. Try to make various signs and sometimes to give meaning or meaning to the signs made.

8. Can hold a pencil properly to write known letters.

9. Trace shapes with precision.

10. Recognizes the names of numbers.

11. Understand the meaning in a simple phrase or sentence.

For the assessment of reading skills, here are some ways to find out reading skills in children:

1. Graded Word List

2. Informal Reading Inventory

3. Cloze procedure

4. Curriculum-based test

5. Oral Reading

6. Reading Comprehension

\subsection{The Implementation of Multisensory Technique}

After identifying and assessing children's reading skills with special needs, prepare steps for remediation according to the type and level of difficulty. Here are some alternatives that can be used as reference material for tutors to improve dyslexia reading skills.

\section{Reading and Spelling Training}

Augur and Briggs developed the Hickey Multisensory Language Course (HMLC) program in 1992. They recognized the importance of learning the alphabet sequentially. Dyslexic children will usually have difficulty learning and remembering the names and sequences of alphabetic letters and understanding that they represent speech sounds that make up words (Reid: 2007, 48).

Furthermore, Reid explained that this program is based on multisensory principles. In addition, the alphabet was introduced using wooden or plastic letters so that the child could see letters, pick them up, feel them with their eyes open or closed and pronounce their sounds. This technique is because the visual, auditory, and tactilekinesthetic learning channels are all used for a common purpose. 
The practice program HMLC provides several activities to help children familiarize themselves with the alphabet. Among them, (1) studying letters sequentially; (2) learn the position of each letter of the alphabet; and (3) mentioning and recognizing the form of letters. In its implementation, this program also involves games and a dictionary to help children become familiar with the sequence of letters and the intended direction. For example, the child needs to know that the letter 'i' comes before the ' $k$ ' and letters in the first half of the alphabet and letters in the second half. The alphabet can be divided into groups, which makes it easy for children to remember which group the letters are in, for example:

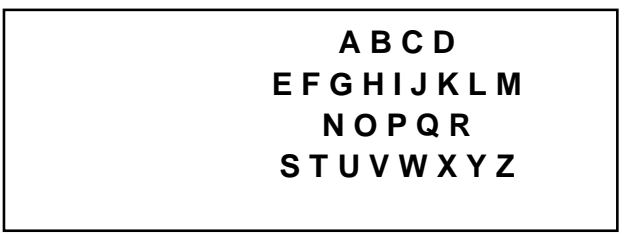

Picture 3. The alphabet group in the HMLC Program

Also, Reid (2007: 49) emphasizes that the HMLC program has activities related to sorting and matching uppercase, lowercase, printed, and handwritten letters; practice sequencing skills with letters and truncated shapes; and practice placing each letter in the alphabet concerning the other letters (this involves finding the missing letter and reversing the order of the alphabet). The program also shows the importance of recognizing where the accent (sound stress) falls in a word, as this affects spelling and rhyme. Rhyme plays are intended to encourage the use of accents by placing accents on different letters. It trains the child's hearing to recognize when a letter has an accent or is emphasized in a word.

The reading and spelling packages in the HMLC program focus on maintaining relationships between sounds and symbols. This process starts with a single letter and continues with consonant combinations, vowel continuation, and complex letter groupings. This reading pack contains a set of cards; on the one hand, the lowercase letters are shown in bold, and the capital letters are shown in the lower right corner to establish a relationship (link) between the two letters. On the back of the card are keywords that contain the sound of the letters, with the actual sound combinations in parentheses. Space is left empty for the child to draw a visual imagination from the keywords. These keywords make the imagination more meaningful to the child and strengthen visual and kinesthetic skills.

In the spelling package, the HMLC program is the same structure as the reading packet. On the front of the card, the sounds that the letters make are shown in brackets, while the back contains the actual sounds and letters. A sound with a spelling option in time will show all possible ways to sound it. Cue words are also displayed on the back as a clue, in case the child forgets. Spelling was seen as very important to these programmers because they saw it as an 'all-around perceptual experience.' The 
multisensory method also involves the child's process in (1) repeating the sound that is heard; (2) feeling the shape made by sounds in the mouth; (3) making sounds and listening; and (4) writing letters.

After the child has been evaluated, the results will show how the child learns best. Some children learn better by means of visual (seeing), auditory (listening), and tactile (touching / feeling). Using a learning style that is appropriate for each child is very important so that they can learn better. The following are examples of learning methods for each child (these suggestions are general and do not have to be used absolutely for every child).

\section{Visual Technique}

Children learn best by seeing the information. Therefore, an excellent way to start is to use a picture card with the word written on the bottom (flashcard). Choose words according to the child's learning level. Also, if the child has difficulty with sounds, indicate to the child how the sounds are made. For example: Show the letter / $t$ / on the card, then point it into your mouth. Make a / $t$ / sound with an exaggerated motion. Let the child imitate your actions while looking in the mirror. Increase it with a syllable combination of 2 letters / ta, ti / and three letters /bag, top/, by making sound and writing. Also, help the child by grouping skills using pictures and words on the daily calendar. Repeat this calendar every day, then mark the tasks as completed.

\section{Auditory Technique}

Children's auditory learns best by listening to what is taught. Children who have difficulty with sound problems, teach a pair of short words and ask the child to say which word is correct (tas/das). Also, have them write letters, words, or sentences while you say them to practice their writing skills. Also, help with your grouping skills by installing a "verbal" (spoken) calendar. Read aloud to the child his daily schedule and help him organize chores and schedules.

\section{Tactile Technique}

These children learn best with the "touching" process. These are the kids commonly seen separating parts of an object and then putting them back together. They learn best by touch, so it is essential to incorporate this learning style into your instruction. 


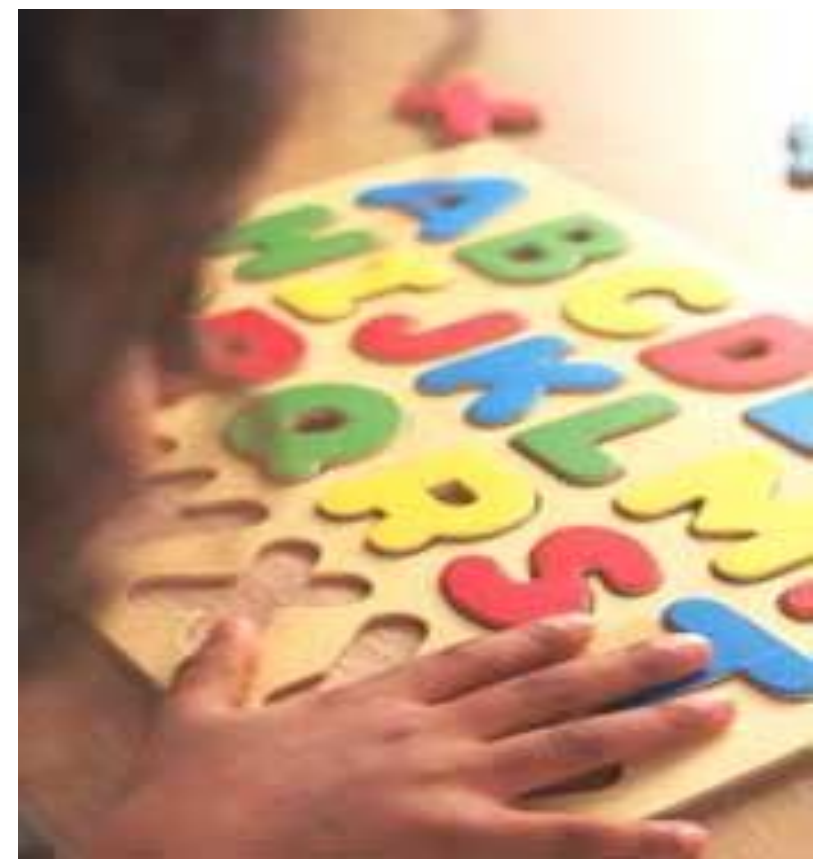

Picture 4. Example letters by combining visual and tactile learning processes.

Create a calendar and mark each important date with embossed/textured stickers. Every day, repeat this calendar with the child and make them touch and feel the sticker. The combination of visual and tactile learning will support the memory.

1. Developing Rhythms and Rhymes

2. Hands were clapping in a circle.

3. Say the name of the children - or another vocabulary.

4. The leader sings the song and the other children follow.

5. Sing a nursery rhyme or song (allow children who cannot follow to sit in front of the leader and look closely at their lips. Hopefully, they will be better positioned to follow).

6. Use picture card rhymes.

7. Teach them the rhyme 'One by one.'

8. Memory

Word Searching

1. Try to direct the child by giving out the first sound of the word or describing its size and color.

2. Give an opposite clue - 'It is not black, it is color .... (white).'

3. Give similar directions - 'Like a rabbit, that is ... (guinea pig).'

4. Short term auditory memory

5. Listen to the story from the cassette, then answer the questions. 
6. Break up the language and ask them to repeat what you just said. If the children find remembering commands to be a problem, start with one first, then make several.

7. Include rote tasks in the curriculum and make sure children are not asked to do something more than they can handle, for example, in music - how to play it; in geography - how to follow directions; in mathematics - how to operate a calculator.

\section{Conclusion}

Physiological and/or biological conditions of children that do not match their academic competence do not comply with the predetermined standard criteria are called children with learning disabilities. Dyslexia is one type of learning disability, namely, a learning disability in the form of reading errors. Academic assessment that is suitable for dyslexic children is needed because they have obstacles in the academic ability. The assessment made by the teacher aims to improve dyslexic reading skills. An assessment that can be used for children with dyslexia is a multisensory technique. The multisensory technique is an alternative used as reference material for teachers to improve the reading skills of dyslexic sufferers. Multisensory Techniques that can be used include 1) Reading and Spelling Training; 2) Visual Technique; 3) Auditory Technique; and 4) Tactile Technique. The reading and spelling focus on maintaining relationships between sounds and symbols starts with a single letter and continues with consonant combinations, vowel continuation, and complex letter groupings. The Visual Technique can begin by using a picture card with the word written on the bottom (flashcard). Auditory technique for children who have difficulty with sound problems, teach a pair of short phrases and ask the child to say which word is correct. In addition, children with dyslexia will have the best learning by touch, so it is essential to incorporate this learning style into the instruction as a tactile technique.

\section{References}

Amelia, W. (2016). Karakteristik dan Jenis Kesulitan Belajar Anak Slow Learner. Jurnal Aisyah: Jurnal Ilmu Kesehatan, 1(2), 53-58.

Damanik, J. B. U. (2017). Analisis Faktor Kesulitan Belajar Siswa Pada Mata Pelajaran Biologi di Kelas XI MIA SMA Negeri 1 Raya Tp 2016/2017 (Doctoral dissertation, Universitas Negeri Medan).

Davis, Ronald D. (1997). The Gift of Dyslexia: Why Some of the Smartest People Can't Read and How They Can Learn. London: Perigee.

Departemen Pendidikan Nasional. 2007. Identifikasi Anak Berkebutuhan Khusus dalam Pendidikan Inklusif. Jakarta: Direktorat Pembinaan Sekolah Luar Biasa.

Fatoni, A. C. H. M. A. D., \& Ainin, I. K. (2019). Identifikasi Siswa Disleksia Di Sekolah Dasar Negeri Inklusi Surabaya Timur. Jurnal Pendidikan Khusus, 12(3), 1-11.

Ghufron, M. N. (2015). Kesulitan belajar pada anak: Identifikasi faktor yang berperan. Elementary: Islamic Teacher Journal, 3(2), 298-311. 
Hammil, D.D. et al. (1981). A New Definition of Learning Disabilities. New York: Prentice Hall Inc.

Harian Kompas.2007. Artikel Anna Surti Ariani, Psi, LD dalam http://www2.kompas.com/ Jumat, 22 Juni 2007

Haryatni, A. P. (2014). Identifikasi faktor-faktor penyebab kesulitan belajar pada siswa SMP Negeri 5 kota Jambi. Skripsitidak diterbitkan. Jambi: FKIP Universitas Jambi.

Hayden, Torey.2000. Mengakomodasi Murid Berkebutuhan Khusus. Tersedia [online] www.torey-hayden.com. Tanggal 25-03-2021.

Kiswantoro, A., Lestari, I., \& Zamroni, E. (2017, August). Konseling Bagi Konseli Berkebutuhan Khusus. In Proceeding Seminar dan Lokakarya Nasional Bimbingan dan Konseling 2017 (Vol. 1, pp. 386-419).

Leko, M. M., Brownell, M. T., \& Lauterbach, A. A. (2010). High-incidence disabilities. Best practices for the inclusive classroom: Scientifically based strategies for success, 25-50.

Lerner, J.W. (1965). Learning Disabilities. New Jersey: Houghton Mifflin Company.

Lorenza, Y. (2019). Analisis Kesulitan Belajar Siswa Pada Materi Pokok Sel di Kelas XI MIA SMA Negeri 2 Medan (Doctoral dissertation, Universitas Negeri Medan).

Martins, V. F., Amato, C., Tomczyk, Ł., Oyelere, S. S., Eliseo, M. A., \& Silveira, I. F. (2020, April). Accessibility Recommendations for Open Educational Resources for people with learning disabilities. In World Conference on Information Systems and Technologies (pp. 387-396). Springer, Cham.

Peer, Lindsay. 2002. Glue Ear An Essential guide for teachers, parents, and health professionals. London: David Fulton Publishers.

Pujaningsih, (2011). Pendidikan Anak Berkesulitan Belajar Spesifik:Yogjakarta. Pengembangan Kompetensi Guru SLB non PLB DINAS DIKPORA.

Reid, Gavin. 2007. Dyslexia. 2nd edition. London: Continuum Publishing Group.

Sadieda, L. U., \& Cahyani, A. E. (2017). Identifikasi Mental Computation Siswa Disleksia dalam Melakukan Operasi Penjumlahan dan Pengurangan Bilangan Bulat. JRPM (Jurnal Review Pembelajaran Matematika), 2(2), 106-119.

Saifudin, M., \& Wijaya, P. (2016). Pengaruh Terapi Musik Klasik Terhadap Tingkat Kecemasan Remaja Putra (13-15 Tahun) (The Effect of Classical Music Therapy at The Level of Adolescents Anxiety (13-15 Years). Journals of Ners Community, 7(1), 21-32.

Silalahi, R. (2020). Analisis Faktor Penyebab Dan Kesulitan Belajar Siswa Pada Materi Jamur Di Kelas X Ipa Sma Swasta Angkasa 1 Laud Medan Tahun Ajaran 2019/2020 (Doctoral dissertation, Universitas Negeri Medan).

Sudarsana, G. N., \& Suarni, N. K. (2020). Pendeteksian Kesulitan Belajar Siswa Berdasarkan Transcript Based Lesson Analysis dalam Proses Pembelajaran Bagi Guru. Proceeding Senadimas Undiksha, 1712. 
Sudarsana, G. N., \& Suarni, N. K. (2020). Pendeteksian Kesulitan Belajar Siswa Berdasarkan Transcript Based Lesson Analysis dalam Proses Pembelajaran Bagi Guru. Proceeding Senadimas Undiksha, 1712.

Suryani, Y. E. (2010). Kesulitan belajar. Magistra, 22(73), 33.

Trijayanti, D. (2019). Layanan Konseling Individu untuk mengatasi Kesulitan Belajar Spesifik Materi Keislaman pada Anak Berkebutuhan Khusus: Penelitian di Sekolah Dasar Laboratorium UPI Cibiru (Doctoral dissertation, UIN Sunan Gunung Djati Bandung).

Ummah, D. M. (2018). Analisis kesulitan belajar pada anak berkebutuhan khusus (ABK) Di SMA Negeri 10 Kota Ternate. Jurnal Bimbingan dan Konseling Terapan, 2(1), 32-40.

Widyorini, E., \& Van Tiel, J. M. (2017). Disleksia: Deteksi, Diagnosis, Penanganan di Sekolah dan di Rumah. Kencana. 